\title{
Prolonged cholestatic jaundice with very high bilirubin level due to hepatitis e infection
}

\author{
Devki Nandan *, Manish Kumar, Vivek Dewan, Chinmaya Kumar Sahoo \\ Department Of Pediatrics PGIMER Dr RML Hospital, New Delhi 110001, India \\ *Corresponding author E-mail: Devkinandan2002@yahoo.com
}

Copyright $\odot 2014$ Devki Nandan et al. This is an open access article distributed under the Creative Commons Attribution License, which permits unrestricted use, distribution, and reproduction in any medium, provided the original work is properly cited.

\begin{abstract}
A 12 year old male child presented with jaundice, generalized itching and disturbed sleep of one and half months duration. Extremely high Serum bilirubin levels (total $38.3 \mathrm{mg} / \mathrm{dl}$, direct $27 \mathrm{mg} / \mathrm{dl}$, and indirect $11 \mathrm{mg} / \mathrm{dl}$ ) with normal liver enzymes were documented, which gradually resolved over next two months on supportive management. Hepatitis E infection was diagnosed based on presence of positive Anti hepatitis E IgM antibodies. Underlying associated hepatobiliary diseases were ruled out on a detailed work-up of the case. This case is a unique example of prolonged cholestatic jaundice with extremely high levels of bilirubin with normal liver enzymes in a case of hepatitis E, which has not been reported previously in pediatric age group.
\end{abstract}

Keywords: high bilirubin, hepatitis E, Cholestatic jaundice, normal liver enzyme, prolonged jaundice.

\section{Introduction}

Hepatitis $\mathrm{E}$ is a fairly common cause of acute viral hepatitis which typically follows a benign course usually lasting for 1-6 weeks [2], [3]. Cholistatic type of clinical presentation in patients with hepatitis $E$ has been infrequently highlighted in the literature [11]. Bilirubin levels reported in the literature varied from 0.6 to $20 \mathrm{mg}$ [11] however; there are reports of extreme values of bilirubin and duration of illness in adults. We recently treated a case of hepatitis $E$ with prolonged jaundice (>12 weeks), extremely high bilirubin levels (levels $38 \mathrm{mg} \%$ ) and normal liver enzymes. This type of presentation is quite unique in cases of HEV infection and has never been reported in the literature.

\section{Case report}

A 12 year male child presented with complains of jaundice, generalized itching and disturbed sleep for last one and half months. History of low grade fever, abdominal pain, occasional vomiting, high colored urine and clay colored stool were also present. There was no history of bleeding tendencies, seizures or altered consciousness. History of blood transfusion or jaundice were absent in the past.

On examination, he was afebrile, yellowish discoloration of eye, palm and sole. Vital parameters (pulse rate, respiratory rate \&blood pressure) and anthropometry (weight and height) were normal. Liver $(4 \mathrm{~cm})$ firm on palpation. Examinations of respiratory, cardiovascular and nervous system were unremarkable. Signs of liver cell failure including as cities, encephalopathy, bleeding etc. were absent.

Investigations at time of admission revealed total serum bilirubin of $31 \mathrm{mg} / \mathrm{dl}$ (direct $14 \mathrm{mg} / \mathrm{dl}$ and indirect- $17 \mathrm{mg} / \mathrm{dl}$ ). Other investigations including SGPT (53U/L), SGOT (68 U/L), ALP (323 U/L), serum protein (albumin $3 \mathrm{gm} / \mathrm{dl}$, globulin3.1gm/dl), PT/ APTT / INR (12.6/34.9 /0.9), hemoglobin (12.2 gm/dl), white blood cell count (10,200/mm3), platelets count (3 lac/cumm) and reticulocyte count were normal. Bile pigment were absent in urine and stool. Renal function tests were within normal limit. Abdominal Ultrasonography revealed hepatomegaly with normal echo-texture. There was no biliary obstruction and ascities.

Anti-Hepatitis E IgM antibody test was positive. HBsAg, Anti HAV and Anti HCV antibodies were negative. $24 \mathrm{hrs}$ urinary copper and serum cerruloplasmin levels for Wilson's disease were within normal limit. G6PD level was normal 
and sickling test was negative which rule out any superimposed hemolysis. C3 and C4 levels were normal; ANA was negative which rule out autoimmune cause of jaundice. HIDA scan done later during course of illness was normal (preserved hepatocyte function and patent hepato biliary enteric pathway). A week later serum bilirubin increased further to $38.3 \mathrm{mg} / \mathrm{dl}$ (direct $27.3 \mathrm{mg} / \mathrm{dl}$ and indirect $11 \mathrm{mg} / \mathrm{dl}$ ) and SGPT/SGOT/ ALP (34/51/759) remained normal. We managed the patient with Ursodeoxycholic acid (300 mg 8 hourly), hydroxyzine (40mg 8 hourly) and other supportive measure (multivitamins \& IV fluids).

Liver function tests were monitored regularly. After a month his bilirubin levels decreased to $5.2 \mathrm{mg} / \mathrm{dl}$ (direct $2.9 \mathrm{mg} / \mathrm{dl}$, indirect $2.3 \mathrm{mg} / \mathrm{dl}$ ) and SGOT/SGPT/ ALP were 49/30/ 520 respectively. He was discharged and his bilirubin levels normalized over next $4 \mathrm{wks}$ period. He remained in good health with normal liver functions during a six month followup.

\section{Discussion}

Hepatitis E infection is a self-limited, enterically transmitted acute viral hepatitis that frequently occur in epidemic outbreaks [1], [2], [3]. Average incubation period is 40 days (range, 15-60 days) and it is usually a mild disease [2]. The mean case fatality rate is $0.5 \%$ to $3 \%$, although it increases up to $25 \%$ in pregnant women [4]. Severity of the illness increases with age and there are higher percentages of anictric and sub-clinical cases in children [1].The highest rates of symptomatic disease have been reported in middle-aged adults. Laboratory findings in patients with HEV hepatitis are found to be similar to other forms of acute viral hepatitis. Resolution of hyperbilirubinemia and elevated aminotransferases generally occurs within 1 to 6 weeks after the onset of illness [5]. Previous studies have shown a serum bilirubin level ranging $6.2 \pm 4.6 \mathrm{mg} / \mathrm{dl}$ [range .6 to $20.11 \mathrm{mg} / \mathrm{dl}$ ] and the clinical course usually last for less than 6 weeks [11]. Laura $M$ et al reported acute hepatitis $E$ in a 70 year old male with prolonged cholastatic jaundice with maximum serum bilirubin of $25 \mathrm{mg} / \mathrm{d}$ [12].

Hepatitis A has been reported to present as chronic cholestatic jaundice, lasting longer than a year [7] however; a prolonged cholestatic picture due to HEV has not been described previously in pediatrics age.

This 12 year old patient had one and half month history of jaundice, and had a positive IgM antibody for hepatitis E. Serum bilirubin level was exceptionally high total-31mg/dl (direct-14mg/dl, indirect-17mg/dl) which increased further to $38 \mathrm{mg} / \mathrm{dl}$ (direct-27mg/dl, indirect-11mg/dl) with only mild elevation of alkaline phosphatase level and other parameters of liver functions were normal. Bilirubin levels declined gradually over next one month to $5 \mathrm{mg} / \mathrm{dl}$.

Exceptionally high serum bilirubin level $(38 \mathrm{mg} / \mathrm{dl})$ with normal liver enzyme which resolved over a prolonged period of time makes this case a unique manifestation of acute HEV infection. There was no evidence of cholecystitis, choledocholithiasis, autoimmune disease, hemolytic disease, drug use or any other associated comorbid condition.

In summary, cases of acute hepatitis E infection may present with extremely high bilirubin levels, with normal liver enzymes which may persist for a prolonged period of time. To the best of our knowledge, this is the first such description related to $\mathrm{HEV}$ in pediatric age group. Thus hepatitis $\mathrm{E}$ should also be considered in the cases with prolonged cholestatic jaundice with exceptional high bilirubin value.

\section{References}

[1] Mast EE, Krawczynski K. Hepatitis E: An Overview. Annu Rev Med 1996:47: 257-66.

[2] Vishwanathan R, Sidhu AS. Infectious Hepatitis: Clinical Finding. Indian J Med. Res 1957; 45(Suppl): 49-58.

[3] Zhuang H, Cao X-Y, Liu C-B, Wang G-M. Enterically Transmitted None A Non B Hepatitis In Cina. In: Shikata T, Purcell RH, Uhida T, Eds. Viral Hepatitis C, D And E. Amsterdam : Excerpta Medica, 1991;277-85

[4] Wong DC, Purcell RH, Sreenivasan MA, Et Al. Epidemic and Endemic Hepatitis in India: Evidence For Non-A, Non-B Hepatitis Virus Etiology. Lancet 1980; 2: 876-9.

[5] Chauhan A, Jameel S, Dilawari J Et Al. Hepatitis E Virus Transmission to A Volunteer. Lancet 1993; 1:149-50.

[6] Karetnyi YV, Favorov MO, Khudyakova NS, Et Al. Serological Evidence for Hepatitis E Virus Infection in Israel. J Med Virol 1995; 45:31620.

[7] Terrault NA, Wright TL. Viral Hepatitis A through G. In: Feldman M, Scharschmidt BF, Sleisenger MH, Eds. Sleisenger and Fordtran's Gastrointestinal and Liver Disease: Pathophysiology/Diagnosis/Management, 6th Ed. Philadelphia: WB Saunders Co, 1998:1123-70.

[8] Vento S, Garofano T, Di Perri G, Et Al. Identification of Hepatitis A Virus as a Trigger for Autoimmune Chronic Hepatitis Type 1 in Susceptible Individuals. Lancet 1991; 337:1183-7.

[9] Sylvan SPE, Hellstrom UB, Hampl H, Et Al. Hepatitis E in Patients with Chronic Autoimmune Liver Disease. JAMA 1995; 273:377-8.

[10] Chow WC, Lee ASG, Lim GK, Et Al. Acute Viral Hepatitis E: Clinical and Serological Studies in Singapore. J Clin Gastroenterol 1997; $24: 235$.

[11] Spectrum Of Hepatitis E Virus Infection In India Mohammed Sultan Khuroo, Vinod K. Rustgi, George J. Dawson, Isa K. Mushahwar, Ghulam Nabi Yattoo, Saleem Kamili, and Bashir Ahmad Khan, Journal Of Medical Virology 43:281-286 (1994).

[12] 12. Laura Mechnik, M.D., Nina Bergman, M.D., Malka Attali, M.D.Et Al. Acute Hepatitis E Virus Infection Presenting As A Prolonged Cholestatic Jaundice. J Clin Gastroenterol 2001; 33(5):421-422. 